\title{
WYKORZYSTANIE KRYMINALISTYCZNYCH BAZ DANYCH PRZEZ POLICYJNE ARCHIWA $X$
}

\begin{abstract}
Streszczenie. Policyjne Zespoły ds. Przestępstw Niewykrytych, zwane potocznie Archiwami X, funkcjonują w ramach komend wojewódzkich policji. Skupiając najbardziej doświadczonych funkcjonariuszy, zajmują się najpoważniejszymi przestępstwami sprzed lat, głównie zabójstwami, których sprawców nie udało się dotychczas wykryć. Kilkuosobowe zespoły dokonują wnikliwej analizy akt niewykrytych przestępstw, docierają do źródeł informacji i wykorzystują najnowsze osiągnięcia kryminalistyki. Szczególnie przydatne są dwie bazy danych: system AFIS oraz baza DNA. Z tego względu właśnie im poświęcono większość tego opracowania.
\end{abstract}

Słowa kluczowe: przestępstwo, baza danych, odciski palców, DNA, Archiwum X.

\section{KRÓTKA CHARAKTERYSTYKA ARCHIWÓW X}

Pierwszy Zespół ds. Niewykrytych Zabójstw został nieoficjalnie powołany w Komendzie Wojewódzkiej Policji w Krakowie w 1999 r. Jego funkcjonowanie zostało sformalizowane w 2005 r. decyzją Komendanta Wojewódzkiego Policji. Funkcjonariusze krakowskiego Archiwum X wykryli ponad 20 zabójstw oraz kilkadziesiąt innych przestępstw (Zajączkowska 2017). W kolejnych latach powstały kilkuosobowe Zespoły ds. Przestępstw Niewykrytych w innych komendach wojewódzkich policji i również mogą się poszczycić dziesiątkami sukcesów.

Praca w zespołach rozpoczyna się od dotarcia do akt niewykrytych zabójstw i innych najpoważniejszych przestępstw, np. w Komendzie Stołecznej Policji wytypowano około 750 takich zdarzeń (Wszytko przed nami 2009). Następnie kolejne akta poddawane są bardzo wnikliwej analizie. Weryfikowane są przyjęte w sprawach wersje śledcze, które z różnych przyczyn zostały odrzucone bądź nie zostały do końca sprawdzone. Funkcjonariusze poszukują śladów i innych dowodów rzeczowych, które nie zawsze znajdują się w aktach. Starają się docierać do świadków zdarzeń oraz rodzin ofiar działań przestępczych. Oprócz pracy operacyjno-śledczej wykorzystywane są najnowsze osiągnięcia kryminalistyki, np. badania genetyczne, daktyloskopijne, fizykochemiczne, wariograficzne,

${ }^{*}$ Uniwersytet Warmińsko-Mazurski w Olsztynie, Wydział Prawa i Administracji, Katedra Kryminalistyki i Medycyny Sądowej, jaroslaw_moszczynski@go2.pl. 
antroposkopijne, cheiloskopijne, otoskopijne, traseologiczne, techniki wizualizacyjne i inne. Szczególnie przydatne w procesie wykrywczym są dwie skomputeryzowane i zautomatyzowane bazy danych w postaci systemu AFIS (Automated Fingerprint Identification System) oraz bazy DNA, które zostaną przybliżone w dalszej części opracowania. Podczas poszukiwania zwłok funkcjonariusze korzystają m.in. z helikoptera wyposażonego w kamerę termowizyjną i georadar. Współpracują z profilerami, psychologami, antropologami, medykami sądowymi oraz ekspertami kryminalistyki. Bardzo ważne jest także współdziałanie z mediami, które nagłaśniają określone sprawy sprzed wielu lat, co ułatwia docieranie do nowych źródeł informacji. Dzięki dedukcji udaje się łączyć fakty pozornie niemające ze sobą nic wspólnego. Każda sprawa traktowana jest w sposób indywidualny, niestereotypowy. Praca w Archiwach X wymaga wielkiej cierpliwości, uważności, nieszablonowego myślenia i doświadczenia.

Policjanci z Archiwów X biorą udział w różnego rodzaju szkoleniach, sympozjach i spotkaniach. Na przykład policjanci z krakowskiego zespołu odwiedzili Akademię FBI w Quantico, gdzie mieli możliwość m.in. zapoznania się z działalnością National Center for the Analysis of Violent Crime (NCAVC). Doskonałą platformą wymiany doświadczeń archiwów stały się konferencje naukowe organizowane przez Studenckie Koło Kryminalistyków na Wydziale Prawa i Administracji Uniwersytetu Łódzkiego, wspierane przez prof. Bogusława Sygita, kierownika Zakładu Kryminalistyki na tej uczelni ${ }^{1}$. Zespoły ds. Przestępstw Niewykrytych doczekały się także naukowych publikacji na ich temat (Gruza, Kupczyński 2012, 7).

\section{PRZED WDROŻENIEM SYSTEMU AFIS}

W 1992 r. w Piotrkowie Trybunalskim i okolicach seryjny zabójca pozbawił życia sześć osób przy użyciu karabinka sportowego. Była wśród nich ekspedientka małego sklepiku, pracownik kantoru, młode małżeństwo, kierowca ciężarówki i emeryt. Po wykryciu sprawca przyznał się do jeszcze jednego zabójstwa (starszej kobiety) w 1986 r. Wspomniane małżeństwo zostało zamordowane w domu podczas snu. Sprawca wszedł do budynku przez piwnicę, wyjmując uprzednio szybę z okienka. W ten sposób pozostawił na niej ślady aż siedmiu palców. Korzystając z tej wyjątkowej okazji, zostały wyprowadzone formuły prawdopodobne (Moszczyński 1988, 1-68). Następnie pracownicy Centralnej Registratury Daktyloskopijnej (CRD), przy pomocy kilku ekspertów z laboratoriów wojewódzkich, podjęli żmudne przeszukiwania zbiorów kart daktyloskopijnych² ${ }^{2}$ Po miesiącu

${ }^{1}$ W dniach 15-16 grudnia 2016 r. odbyła się II Ogólnopolska Konferencja Naukowa „Policyjne Archiwa X".

2 Autor był wówczas naczelnikiem Wydziału Daktyloskopii Centralnego Laboratorium Kryminalistycznego Komendy Głównej Policji, gdzie znajdują się zbiory CRD. 
udało się natrafić na kartę daktyloskopijną sprawcy. Okazało się, że był to cieszący się dobrą opinią rencista, zdaktyloskopowany w młodości w związku z kradzieżą motocykla (Dudziec 1992, 1). Tragizm tego przypadku powiększył fakt, iż podczas przeszukiwania zbiorów CRD sprawca pozbawił życia dwie ostatnie ofiary. Karę śmierci, orzeczoną w 1993 r., zamieniono na karę dożywotniego więzienia, którą skazany odbywa do chwili obecnej. Gdyby nie ślady aż siedmiu palców, które sprawca pozostawił na miejscu zdarzenia, prawdopodobnie nadal cieszyłby się wolnością.

CRD nie była wówczas skomputeryzowana i funkcjonowała na podstawie dziesięciopalcowych formuł daktyloskopijnych (Horoszowski 1958, 381-400). Gdyby już wtedy był wykorzystywany system automatycznej identyfikacji daktyloskopijnej (AFIS), to do wykrycia tego, jak również wielu innych sprawców przestępstw, wystarczyłyby pojedyncze, nawet fragmentaryczne ślady linii papilarnych.

Klasyczne zbiory kart daktyloskopijnych zorganizowane według dziesięciopalcowej formuły daktyloskopijnej, umożliwiały ustalanie tożsamości (lub jej weryfikację) osób podejrzanych o popełnianie przestępstw, a także zwłok. Warunkiem koniecznym do dokonania takich ustaleń była wcześniejsza rejestracja daktyloskopijna danej osoby. Zbiory CRD, podobnie jak wszystkie registratury daktyloskopijne, były, niestety, niemal zupełnie nieprzydatne do wykrywania sprawców przestępstw na podstawie śladów z miejsc zdarzeń, ponieważ te zazwyczaj nie pozwalały na wyprowadzanie dziesięciopalcowej formuły daktyloskopijnej. Jedynie w wyjątkowych przypadkach, kiedy sprawca pozostawił na miejscu zdarzenia ślady większości palców, można było wykonać niepełną kartę daktyloskopijną i wyprowadzić szereg formuł prawdopodobnych.

Pierwsza registratura daktyloskopijna została założona przez Edwarda Henry'ego w Scotland Yardzie w 1901 r. Organizacja kart daktyloskopijnych była oparta na systemie klasyfikacji Henry'ego-Galtona, który został wkrótce wprowadzony w dominiach i koloniach angielskich oraz w Stanach Zjednoczonych Ameryki Północnej. Odmienną klasyfikację dziesięciopalcową opracował Juan Vucetich i znalazła ona zastosowanie w krajach Ameryki Południowej. Podstawy tego systemu były też wykorzystane m.in. w registraturze szwajcarskiej, norweskiej, chińskiej i słowackiej. W wielu państwach stosowano kombinację obydwu tych systemów. Przykładem jest system Roschera, opracowany na potrzeby policji hamburskiej, oraz system Lebiediewa, który wprowadzono do praktyki w Rosji carskiej. Na systemie Roschera oparta była także klasyfikacja daktyloskopijna w Japonii. Wykorzystywany w Polsce system klasyfikacyjny stanowił modyfikację berlińskiego systemu Klatta (Moszczyński 1997, 183-188).

Formuły daktyloskopijne wykorzystywane w systemach klasyfikacji dziesięciopalcowej zawierają informacje o wzorach linii papilarnych występujących na opuszkach wszystkich dziesięciu palców osoby, takie jak typ wzoru, indeksy wzorów pętlicowych oraz subklasy wzorów wirowych. 
Jak już wspomniano, registratury daktyloskopijne służyły głównie do ustalania tożsamości osób i zwłok. W polskiej CRD bardzo popularne były tzw. wywiady daktyloskopijne przez telefon (Raczyński, Skopiński 1961, 5-75). Dzwoniący z kraju funkcjonariusze (najczęściej eksperci daktyloskopii lub technicy) opisywali podstawowe elementy budowy wzorów linii papilarnych na kolejnych palcach i na tej podstawie wyprowadzane były formuły daktyloskopijne. Czynność ta wymagała od pracowników CRD nie tylko perfekcyjnej znajomości zasad klasyfikacji kart daktyloskopijnych i wielkiego doświadczenia, lecz także dużej wyobraźni. Dzięki temu znakomita większość ustaleń przez telefon okazywała się trafna - każdy taki wywiad wymagał potwierdzenia poprzez przesłanie karty daktyloskopijnej do CRD.

Problem braku możliwości wykorzystywania registratur daktyloskopijnych do wykrywania sprawców przestępstw na podstawie śladów linii papilarnych ujawnianych na miejscach zdarzeń (ślady pojedynczych, a nawet kilku palców nie pozwalają na wyprowadzenie formuł dziesięciopalcowych) próbowano rozwiązać za pomocą zbiorów monodaktyloskopijnych, opartych na oddzielnej klasyfikacji wzorów linii papilarnych na poszczególnych palcach. Do najbardziej znanych systemów klasyfikacyjnych monodaktyloskopijnych należał system Battleya (Moszczyński 1997, 188-190). W CRD do lat 70. ubiegłego wieku także prowadzono zbiór monodaktyloskopijny, zawierający odbitki linii papilarnych najbardziej aktywnych przestępców. Prowadzenie registratur monodaktyloskopijnych napotykało jednak na wiele trudności i nie przynosiło oczekiwanych rezultatów. Klasyfikacja odbitek poszczególnych palców oddzielnie była bardzo pracochłonna, a poszczególne formuły szybko się przepełniały, tzn. wiele odbitek palców posiadało taką samą formułę. W tej sytuacji szansę na niewielki sukces miały jedynie małe, regionalne zbiory.

Na przełomie lat 80 . i 90 . XX w. prowadzone były w Polsce zbiory śladów N.N. Eksperci z laboratoriów wojewódzkich mieli obowiązek gromadzenia fotogramów śladów z miejsc zdarzeń, które spełniały odpowiednie wymagania jakościowe i pozostawały niezidentyfikowane po badaniach eliminacyjnych. Ślady te należało porównywać z kartami daktyloskopijnymi osób podejrzanych, nadsyłanymi w ramach kolejnych ekspertyz. Wielka pracochłonność tego przedsięwzięcia także nie przyniosła oczekiwanych rezultatów.

Komputeryzacja zbiorów monodaktyloskopijnych w postaci tzw. systemów półautomatycznych stanowiła pewien postęp, ale jeszcze nie przełom. Działanie tych systemów polegało na kodowaniu śladów i odbitek z kart daktyloskopijnych przez ekspertów, wprowadzaniu kodów do odpowiednio zaprogramowanego komputera i automatycznego porównywania kodów. Systemy takie funkcjonowały w policjach niektórych państw. W Polsce także powstało kilka projektów tego rodzaju rozwiązań (np. Szota-Koziczak 1985, 635-640; Owoc 1986, 213-218). W roku 1988 w Wydziale Daktyloskopii Zakładu Kryminalistyki Komendy Głównej Milicji Obywatelskiej (obecnie: Centralne Laboratorium Kryminalistyczne Policji) uruchomiony został pilotażowy system półautomatyczny, oparty na opracowaniu autora (Moszczyński 1986, 23-27). Po kilku miesiącach 
pracy w czteroosobowym zespole uzyskano pierwsze rezultaty w postaci identyfikacji kilkunastu sprawców kradzieży z włamaniem.

Po roku 1989 autor miał możliwość odwiedzenia laboratoriów kryminalistycznych w państwach Europy Zachodniej i zapoznania się z systemami AFIS oraz nowoczesnymi metodami wizualizacji śladów, co zmieniło kierunek dalszego rozwoju polskiej daktyloskopii.

\section{WDROŻENIE SYSTEMU AFIS}

Pierwszy automatyczny system identyfikacji daktyloskopijnej został wyprodukowany w 1978 r. przez amerykańską firmę Printrak. Wkrótce producentem systemów AFIS została także francuska firma Morpho Systemes oraz japoński koncern NEC. Na przełomie lat 80. i 90. dołączył drugi producent amerykański - Cogent oraz rosyjski PAPIŁON.

W Polsce system centralny AFIS uruchomiony został w 2000 r., zaś w dwa lata później działała już sieć krajowa. Jest to system firmy Morpho. Stanowiska robocze systemu zostały zainstalowane w Centralnym Laboratorium Kryminalistycznym Komendy Głównej Policji oraz wszystkich laboratoriach kryminalistycznych komend wojewódzkich policji. Wcześniej uzyskano niezbędne środki finansowe z unijnego funduszu Phare, dokonano adaptacji pomieszczeń, uzyskano dostęp do policyjnych łączy teleinformatycznych, zaprojektowano krajową sieć systemu AFIS oraz przeprowadzono szkolenia ekspertów³.

Centralny system AFIS zawiera bazę danych, zespół urządzeń kodujących i porównujących oraz 10 stanowisk roboczych. Sieć krajowa zawierała w początkowym etapie jej funkcjonowania 28 stanowisk roboczych oraz 58 urządzeń MorphoTouch do szybkiej identyfikacji osób, wykorzystywanych w jednostkach policyjnych niższego szczebla. System jest stale unowocześniany i rozbudowywany - w późniejszym okresie zainstalowano m.in. 385 stanowisk do rejestracji danych identyfikacyjnych osób oraz 152 urządzenia MorphoRapID (Kot, Tomaszycki 2015, 332-348).

Wdrożenie systemu AFIS stało się przełomem w zakresie wykrywania sprawców przestępstw na podstawie śladów linii papilarnych. Porównanie śladu jednego palca z kilkumilionowym zbiorem kart daktyloskopijnych CRD przez ekspertów było niewykonalne, natomiast system AFIS dokonuje tego w kilkanaście minut.

W bazie systemu AFIS w połowie 2016 r. znajdowało się:

- 3840983 karty daktyloskopijne,

-245657 odbitek dłoni,

- 109442 ślady z miejsc zdarzeń.

\footnotetext{
${ }^{3}$ Koordynację wdrożenia systemu AFIS powierzył Komendant Główny autorowi.
} 
Wprowadzenie odbitek z kart daktyloskopijnych oraz śladów z miejsc zdarzeń do bazy AFIS polega na ich zeskanowaniu i automatycznym zakodowaniu - konwersji obrazu linii papilarnych na kod matematyczny zawierający współrzędne początków i zakończeń oraz rozwidleń i złączeń linii papilarnych.

W ramach przeszukań bazy AFIS dokonuje się następujących porównań:

1) nowa karta - baza kart (TP - TP),

2) nowa karta - baza śladów (TP - ULP),

3) nowy ślad - baza kart (LP - TP),

4) nowy ślad - baza śladów (LP - ULP).

Dzięki porównaniom TP - TP ustalana/weryfikowana jest tożsamość osób i zwłok. Porównania TP - ULP pozwalają na wykrycie wcześniejszych przestępstw popełnionych przez aktualnie rejestrowanego sprawcę. Porównania typu LP - TP dają możliwość ustalenia sprawcy, który został zarejestrowany w związku z innymi przestępstwami. Ostatni rodzaj porównań, LP - ULP, daje szansę na skojarzenie miejsc przestępstw, na których działali ci sami sprawcy.

Dzięki systemowi AFIS każdego roku wykrywa się kilka tysięcy sprawców przestępstw oraz ustala się tożsamość średnio ok. 15000 osób i 500 zwłok. Ślady daktyloskopijne znajdujące się w aktach starych spraw, wykorzystywane przez funkcjonariuszy Archiwów X, prowadzą po latach do zaskoczonych sprawców.

Należy dodać, iż równocześnie z wdrożeniem systemu AFIS powstała także w Wydziale Daktyloskopii CLK KGP pracownia wizualizacji, wyposażona w najnowocześniejszy sprzęt i technologie służące do skutecznego ujawniania śladów linii papilarnych na różnych podłożach. Podobne pracownie zostały zorganizowane również w policyjnych laboratoriach wojewódzkich.

\section{GENETYCZNA REWOLUCJA W KRYMINALISTYCE}

Historia identyfikacji na podstawie profili DNA jest krótka i liczy zaledwie około trzech dekad, ale nie ulega wątpliwości, że jest to niezwykle skuteczna metoda identyfikacji osób na podstawie nawet znikomych ilości materiału biologicznego. Wcześniej ślady biologiczne służyły jedynie do identyfikacji grupowej. Obecnie pozwalają na identyfikację indywidualną, choć niechętnie tak nazywaną. Wykorzystanie genetyki na potrzeby kryminalistyki zawdzięczamy głównie dwóm osobom: Alec Jeffreys odkrył sondy molekularne i opisał metodę zwaną DNA fingerprinting, zaś Kary B. Mullis odkrył i opracował reakcję PCR.

Identyfikacja genetyczna człowieka opiera się głównie na analizie DNA genomowego, zawartego $\mathrm{w}$ jądrach komórek, a rzadziej przy wykorzystaniu DNA mitochondrialnego (mtDNA), znajdującego się w mitochondriach. DNA jądrowe stanowi indywidualny kod genetyczny każdego człowieka, z wyjątkiem bliźniąt monozygotycznych. Najczęstszym źródłem DNA jądrowego w praktyce 
kryminalistycznej jest krew, ślina, nasienie, wydzielina z dróg rodnych oraz cebulki włosów. W kryminalistycznych badaniach genetycznych coraz częściej wykorzystywane są również tzw. ślady kontaktowe w postaci substancji potowotłuszczowej, tworzącej ślady daktyloskopijne zawierające złuszczone komórki naskórka (Młodziejowski, Sołtyszewski 2007, 125-186). Identyfikacja genetyczna zdeklasowała identyfikację daktyloskopijną pod względem podstaw naukowych. Chodzi głównie o możliwość dokładnego oszacowania wiarygodności uzyskanych wyników badań porównawczych profili DNA. W przypadku stwierdzenia zgodności takich profili dokonuje się obliczeń wartości ilorazu wiarygodności lub prawdopodobieństwa ich przypadkowej zbieżności, przy wykorzystaniu populacyjnych baz danych (Sołtyszewski i in. 2002, 88-93).

Eksperci nie stosują zazwyczaj sformułowań kategorycznych typu: „Ślad pochodzi od podejrzanego" nawet wówczas, gdy wartość ilorazu wiarygodności jest bardzo wysoka. Najczęściej używane jest sformułowanie: „Ślad pochodzi od podejrzanego z prawdopodobieństwem graniczącym z pewnością". Praktyka taka wynika z zastosowania obliczeń statystycznych do oceny wartości dowodu i jest raczej wyrazem precyzji ustaleń, niż braku ich pewności. Warto przy tym zauważyć, że stosowane obecnie zestawy do genotypowania pozwalają na uzyskanie niezwykle małego (rzędu $10^{-28}$ ) prawdopodobieństwa przypadkowego powtórzenia się profili DNA u różnych osób, co jest komentowane następująco: „biorąc pod uwage prawa genetyki populacyjnej oraz reguły prawdopodobieństwa nie pojawi się inna, niespokrewniona, przypadkowa osoba z populacji, która będzie miała taki sam profil DNA. Co więcej, takiej osoby także nie było od początku istnienia gatunku" (Achrem 2016, 39-56).

\section{KRYMINALISTYCZNE BAZY DNA}

Pierwsza i największa europejska baza genetyczna powstała w Wielkiej Brytanii już w 1995 r. Wkrótce zaczęto organizować podobne bazy w innych krajach europejskich (Filewicz, Sołtyszewski 2003, 5-12). Skomputeryzowane bazy DNA działają podobnie do daktyloskopijnych systemów AFIS. Do takich baz wprowadzane są profile DNA podejrzanych oraz profile oznaczane na podstawie śladów biologicznych z miejsc zdarzeń. Ich automatyczne porównywanie daje możliwość ustalania tożsamości osób i zwłok, wykrywania sprawców przestępstw oraz kojarzenia zdarzeń, w których działali ci sami sprawcy.

W Polsce przygotowania do utworzenia bazy DNA rozpoczęto w Centralnym Laboratorium Kryminalistycznym KGP na przełomie lat 1998/1999. Polegały one m.in. na opracowaniu stosownych podstaw prawnych, przeszkoleniu ekspertów w Forensic Science Service, gdzie wówczas prowadzona była brytyjska baza danych DNA, przygotowaniu odpowiedniej infrastruktury oraz wyposażeniu policyjnych laboratoriów genetycznych w nowoczesną aparaturę (Goc, Dąbrowska 
2002, 5-7). Ostatecznie polska baza danych DNA została uruchomiona w roku 2007. Gromadzi się w niej i przetwarza profile genetyczne:

- osób wymienionych w art. 74 i 192a k.p.k., tj. oskarżonych i podejrzanych,

- osób o nieustalonej tożsamości oraz osób usiłujących ukryć swoją tożsamość,

- zwłok ludzkich o nieustalonej tożsamości,

- osób stwarzających zagrożenie, o których mowa w ustawie z dnia 22 listopada 2013 r. o postępowaniu wobec osób z zaburzeniami psychicznymi stwarzających zagrożenie życia, zdrowia lub wolności seksualnej innych osób (Dz. U. 2014, poz. 24 ze zm.),

- śladów nieznanych sprawców przestępstw, np. śladów znalezionych na miejscu przestępstwa, gdy ich pochodzenia nie można przypisać do konkretnej osoby,

- osób zaginionych,

- osób spokrewnionych z osobami zaginionymi.

Polska baza danych DNA jest, niestety, ciągle bardzo mała - jej stan na dzień 30 września $2016 \mathrm{r}$. przedstawiony został w tab. 1. Dla porównania, w tab. 2 zestawiono wielkości baz danych DNA w wybranych państwach europejskich.

Tabela 1. Liczba profili DNA zarejestrowanych w polskiej bazie danych DNA - stan na dzień 30 września 2016 r.

\begin{tabular}{|l|c|}
\hline \multicolumn{1}{|c|}{ Kategoria profilu } & Liczba profili DNA \\
\hline Podejrzani & 52444 \\
\hline Ślady nieznanych sprawców przestępstw & 7131 \\
\hline Zwłoki o nieustalonej tożsamości & 1035 \\
\hline Osoby o nieustalonej tożsamości lub ukrywające tożsamość & 30 \\
\hline Osoby zaginione & 1782 \\
\hline Krewni osób zaginionych & 62760 \\
\hline Suma & 338 \\
\hline
\end{tabular}

Źródło: Centralne Laboratorium Kryminalistyczne Policji.

Tabela 2. Wielkości baz danych DNA w wybranych państwach europejskich - stan na rok 2015

\begin{tabular}{|l|c|c|}
\hline \multicolumn{1}{|c|}{ Państwo } & $\begin{array}{c}\text { Liczba profili DNA osób } \\
\text { (w tys.) }\end{array}$ & Procent populacji \\
\hline 1 & 2 & 3 \\
\hline Wielka Brytania & 6000 & 10,0 \\
\hline Francja & 3100 & 6,0 \\
\hline Niemcy & 850 & 1,0 \\
\hline
\end{tabular}




\begin{tabular}{|l|c|c|}
\hline \multicolumn{1}{|c|}{1} & 2 & 3 \\
\hline Hiszpania & 313 & 0,7 \\
\hline Holandia & 225 & 1,3 \\
\hline Austria & 197 & 2,5 \\
\hline Czechy & 174 & 1,7 \\
\hline Finlandia & 157 & 3,0 \\
\hline Szwecja & 148 & 1,5 \\
\hline Węgry & 138 & 1,4 \\
\hline Litwa & 90 & 2,3 \\
\hline Słowacja & 55 & 1,0 \\
\hline Estonia & 48 & 3,2 \\
\hline Polska & 45 & 0,1 \\
\hline
\end{tabular}

Źródło: opracowano na podstawie danych Rady Unii Europejskiej (Council Decision 2008/615/JHA, Council Decision 2008/616/JHA).

Niewielkie rozmiary polskiej bazy DNA sytuują ją wśród najmniejszych europejskich baz genetycznych, natomiast w odniesieniu do liczby mieszkańców poszczególnych państw - na samym końcu. Od jej wielkości i aktualności zależą możliwości wykrywania sprawców przestępstw na podstawie śladów biologicznych. Gdzie zatem leży problem?

\section{NIESPRZYJAJĄCE PODSTAWY PRAWNE}

Rejestracja kryminalistyczna, a w szczególności daktyloskopijna i genetyczna jest znacznie ograniczona poprzez obowiązujące w tym zakresie podstawy prawne. W roku 2005 Trybunał Konstytucyjny, uwzględniając wniosek Rzecznika Praw Obywatelskich, wydał orzeczenie z dnia 12 grudnia 2005 r. (sygn. K 32/04), w którym zakwestionował przepisy ustawy o Policji dotyczące rejestracji daktyloskopijnej, stwierdzając m.in., że art. 20 ust. 2 ustawy o Policji jest niezgodny z art. 51 ust. 2 w związku z art. 31 ust. 3 Konstytucji przez to, że nie precyzuje, w jakich sytuacjach można gromadzić informacje o osobach podejrzanych o popełnienie przestępstwa ściganego z urzędu, i nie określa rodzajów tych informacji w sposób wyczerpujący. W związku z powyższym w roku 2006 art. 20 ustawy o Policji został znowelizowany m.in. w ten sposób, iż w ust. 2c zapisano: „Informacji, o których mowa w ust. 2a, nie pobiera się w przypadku, gdy nie mają one przydatności wykrywczej, dowodowej lub identyfikacyjnej w prowadzonym postępowaniu". Przepis ten jest interpretowany w taki sposób, że jeśli na miejscu zdarzenia nie zostaną ujawnione 
ślady linii papilarnych, to osób podejrzanych nie daktyloskopuje się. Analogicznie postępuje się w odniesieniu do profili DNA - jeśli nie są ujawnione ślady biologiczne, to nie dokonuje się wymazów śliny podejrzanych.

W rezultacie polska baza DNA należy do najmniejszych w Europie, zaś aktualizacja bazy systemu AFIS znacznie spowolniła w ostatniej dekadzie, co przedstawiono w tab. 3 .

Tabela 3. Wpływ kart daktyloskopijnych do bazy AFIS oraz wyniki przeszukań typu karta/karta w latach 2005-2015

\begin{tabular}{|c|c|c|c|}
\hline Rok & $\begin{array}{c}\text { Liczba kart } \\
\text { daktyloskopijnych }\end{array}$ & $\begin{array}{c}\text { Przeszukania } \\
\text { karta/karta }\end{array}$ & $\begin{array}{c}\text { Pozytywny wynik } \\
\text { karta/karta }\end{array}$ \\
\hline 2005 & 335806 & 485866 & 140504 \\
\hline 2006 & 216394 & 354277 & 125993 \\
\hline 2007 & 240548 & 328736 & 79183 \\
\hline 2008 & 135852 & 212933 & 69198 \\
\hline 2009 & 51350 & 113455 & 52737 \\
\hline 2010 & 91741 & 117954 & 27906 \\
\hline 2011 & 75660 & 82849 & 20556 \\
\hline 2012 & 76968 & 97057 & 22434 \\
\hline 2013 & 148649 & 158767 & 30095 \\
\hline 2014 & 98860 & 111916 & 28071 \\
\hline 2015 & 79816 & 99946 & 21857 \\
\hline
\end{tabular}

Źródło: Centralne Laboratorium Kryminalistyczne Policji.

Nowoczesny, kosztowny system AFIS, stanowiący bardzo użyteczne narzędzie do zwalczania przestępczości, bez aktualizowanej bazy danych będzie coraz mniej efektywny, a baza DNA długo będzie pozostawała w początkowej fazie rozwoju. Fakt, że na miejscu zdarzenia nie ujawniono śladów linii papilarnych czy śladów biologicznych nie powinien stanowić żadnej przeszkody w pobraniu odcisków palców bądź wymazów śliny od podejrzanego, a zwłaszcza oskarżonego i skazanego. Aktualny stan prawny w tym zakresie jest zaprzeczeniem sensu prowadzenia kryminalistycznych baz danych. Sprawców przestępstw powinno się daktyloskopować (oraz pobierać od nich wymazy śliny na potrzeby bazy DNA) nie tylko w celu wykonania ekspertyz w prowadzonych aktualnie postępowaniach, lecz także w celu umożliwienia wykrywania ewentualnych przestępstw popełnionych w okresie wcześniejszym lub późniejszym. Właśnie do tego służą kryminalistyczne bazy danych, a zwłaszcza systemy AFIS i bazy DNA, stale rozwijane w innych państwach. 


\section{PODSUMOWANIE}

Ciągły rozwój kryminalistyki stwarza nowe możliwości wykrywczo-dowodowe. Korzystają z nich także policyjne Archiwa X, sięgające do niewykrytych spraw z przeszłości. Szczególnie ważne w tym zakresie są system AFIS oraz baza DNA. Efektywność daktyloskopijnej oraz genetycznej bazy danych zależy w oczywisty sposób od ich wielkości oraz stałej aktualizacji. Niestety, obowiązujące podstawy prawne rejestracji kryminalistycznej nie sprzyjają ich rozwojowi.

\section{BIBLIOGRAFIA}

Achrem, Wojciech. 2016. „Proces indywidualizacji w kryminalistycznych badaniach genetycznych”. W Przestępczość, dowody, prawo. Księga jubileuszowa prof. Bronisława Młodziejowskiego. Red. Jarosław Moszczyński, Denis Solodov, Ireneusz Sołtyszewski. 39-56. Olsztyn: Wydawnictwo Uniwersytetu Warmińsko-Mazurskiego.

Babecka, Jolanta. 2002. „Skóra jako źródło śladów kryminalistycznych w kontekście badań DNA”. W Aktualne zagadnienia biologii kryminalistycznej. Red. Ireneusz Sołtyszewski. 61-68. Warszawa: Wydawnictwo Centralne Laboratorium Kryminalistyczne Komendy Głównej Policji.

Dudziec, Ireneusz. 1992. „Z ręki rencisty”. Gazeta Wyborcza. 28 lipca.

Filewicz, Andrzej, Ireneusz Sołtyszewski. 2003. „Bazy DNA w Europie - rozwiązania legislacyjne". Problemy Kryminalistyki 241: 5-12.

Goc, Mieczysław, Halina Dąbrowska. 2002. „Polska baza DNA dziś i jutro”. Problemy Kryminalistyki 237: 5-7.

Gruza, Ewa, Jędrzej Kupczyński (red.). 2012. Archiwa X. Zagadnienia kryminalistyczne, procesowe i materialnoprawne. Warszawa: Stowarzyszenie Absolwentów Wydziału Prawa i Administracji Uniwersytetu Warszawskiego.

Grzesiak, Grzegorz, Tomasz Konopka, Marek Lech. 2007. „DNA zabójcy na szyi ofiary zadławienia”. Problemy Kryminalistyki 257: 55-58.

Horoszowski Paweł. 1958. Kryminalistyka. Warszawa: PWN.

Konopka, Tomasz, Ewa Kaczor, Adam Gross, Filip Bolechała, Krzysztof Woźniak, Marcin Strona, Artur Moskała. 2007. „Zabójstwa sprzed lat badane we współpracy z policyjnym Archiwum X". Annales Academiae Stetinensis 53, Suppl. 2: 13-16.

Kot, Edyta, Krzysztof Tomaszycki. 2015. „Funkcjonowanie automatycznego systemu identyfikacji daktyloskopijnej”. W Przestępczość w XXI wieku. Zapobieganie i zwalczanie. Problemy technologiczno-informatyczne. Red. Emil W. Pływaczewski, Wojciech Filipkowski, Zbigniew Rau. 332-348. Warszawa: Wolters Kluwer.

Młodziejowski, Bronisław, Ireneusz Sołtyszewski. 2007. „Ślady biologiczne”. W Ślady kryminalistyczne. Ujawnianie, zabezpieczanie, wykorzystanie. Red. Mieczysław Goc, Jarosław Moszczyński. 125-186. Warszawa: Difin.

Moszczyński, Jarosław. 1986. „Możliwości kodowania śladów linii papilarnych zabezpieczonych na miejscu zdarzenia". Problemy Kryminalistyki 171: 23-27.

Moszczyński, Jarosław. 1988. Najbardziej prawdopodobne formuły daktyloskopijne. Warszawa: Wydawnictwo Zakładu Kryminalistyki Komendy Głównej Milicji Obywatelskiej.

Moszczyński, Jarosław. 1997. Daktyloskopia. Zarys teorii i praktyki. Warszawa: Wydawnictwo Centralnego Laboratorium Kryminalistycznego Komendy Głównej Policji.

Owoc, Mirosław. 1986. „Wirtualna registratura monodaktyloskopijna”. Problemy Kryminalistyki 172: 213-218. 
Raczyński, Dominik, Zygmunt Skopiński. 1961. Wywiad daktyloskopijny przez telefon. Warszawa: Wydawnictwo Zakładu Kryminalistyki Komendy Głównej Milicji Obywatelskiej.

Sołtyszewski, Ireneusz, Anna Niemcunowicz-Janica, Witold Pepiński, Jerzy Janica. 2002. „Genetyka populacyjna układów HumFES/FPS i HumF13B w populacji północno-wschodniej Polski". Zeszyty Metodyczne 15: 88-93.

Szota-Koziczak, Anna. 1985. „Skomputeryzowana registratura monodaktyloskopijna - propozycja badania odcisku palca wzdłuż biegu linii naturalnych”. Problemy Kryminalistyki 170: 635-640.

\title{
Akty prawne
}

Council Decision 2008/615/JHA of 23 June 2008 on the stepping up of cross-border cooperation, particularly in combating terrorism and cross-border-crime.

Council Decision 2008/616/JHA of 23 June 2008 on the implementation of Council Decision 2008/615/JHA of 23 June 2008 on the stepping up of cross-border cooperation, particularly in combating terrorism and cross-border-crime ("Prüm Decisions"). Statistics and reports on automated data exchange for 2015. http://statewatch.org/news/2016/apr/eu-council-prumstatistics-2015-dna-fingerprints-vrd-05129-16.pdf [dostęp 24.11.2016].

\section{Strony internetowe}

Wszytko przed nami.2009.ZDariuszem Piotrowiczem, psychologiem policyjnym zKomendy Stołecznej Policji, rozmawia Mariusz Góra. http://www.policja.pl/pol/aktualnosci/41763,Wszystko-przed-nami.html [dostęp: 10.02.2017].

Zajączkowska, Joanna. 2017. Archiwum X istnieje naprawdę. http://wiadomosci.onet.pl/na-tropie/ archiwum-X-istnieje-naprawde/012mp [dostęp: 10.02.2017].

Jarostaw Moszczyński

\section{USE OF FORENSIC DATABASES BY POLICE X ARCHIVES}

\begin{abstract}
Police Teams Dealing with Undetected Crime, commonly referred to as the $\mathrm{X}$ Archives, operate within the voivodship police headquarters. They accumulate the most experienced officers and deal with the most serious crimes from the past, mainly the murders whose perpetrators have not been detected so far. The teams of several people make a thorough analysis of the acts of undetected crimes, they reach sources of information and use the latest achievements of forensic science. Two databases are particularly useful, i.e. AFIS and DNA. For this reason, the most attention has been given to them.
\end{abstract}

Keywords: crime, database, fingerprints, DNA, X Archives. 